\title{
Correction: Increased non-typhoidal Salmonella hospitalizations in transfusion-naïve thalassemia children: a nationwide population-based cohort study
}

Jiunn-Ming Sheen, Fang-Ju Lin, Yao-Hsu Yang and Kuang-Che Kuo iD

(c) The Author(s) 2021

Pediatric Research (2022) 91:1917; https://doi.org/10.1038/s41390-021-01662-9

Correction to: Pediatric Research https://doi.org/10.1038/s41390-

021-01602-7, published online 19 June 2021

In the original article, the order of authors was wrong and a footnote was missing. The original article has been corrected.

\begin{abstract}
(c) Open Access This article is licensed under a Creative Commons Attribution 4.0 International License, which permits use, sharing, appropriate credit to the original author(s) and the source, provide a link to the Creative Commons license, and indicate if changes were made. The images or other third party material in this article are included in the article's Creative Commons license, unless indicated otherwise in a credit line to the material. If material is not included in the article's Creative Commons license and your intended use is not permitted by statutory regulation or exceeds the permitted use, you will need to obtain permission directly from the copyright holder. To view a copy of this license, visit http://creativecommons. org/licenses/by/4.0/.
\end{abstract}

(c) The Author(s) 2021 